Pak. j. sci. ind. res. Ser. A: phys. sci. 201457 (2) 74-85

\title{
Evaluation of Free Radical Scavenging Activity of Tea Infusion of Commercial Tea Products Available in UAE
}

\author{
Fazilatun Nessa* and Saeed Ahmed Khan \\ Department of Pharmaceutical Chemistry and Natural Products, Dubai Pharmacy College, \\ P.O. Box 19099, Dubai, United Arab Emirates
}

(received September 25, 2012; revised November 19, 2012; accepted December 5, 2012)

\begin{abstract}
In the present study, twenty four commercial tea samples were assayed to determine their free radical scavenging activity and polyphenolic contents based on the brewing/infusing period. Tea samples were infused/brewed in $200 \mathrm{~mL}$ boiled water at $120{ }^{\circ} \mathrm{C}$ for 1,2 and $5 \mathrm{~min}$, respectively. The radical scavenging activities of tea infusion/brewing were measured using 1,1-diphenyl-2-picrylhydrazyl radical (DPPH) assay method. The results were ranged from $67.81-90.51 \%$ for black tea bags, $90.37-94.51 \%$ for green tea bags, $24.66-92.25 \%$ for black tea powder, $16.08-93.06 \%$ for green tea powder and 32.90 $45.54 \%$ for Camomile herbal infusion. The results showed that 1 or 2 min black tea bags infusion exhibited highest radical scavenging activity than $5 \mathrm{~min}$ infusion. Antioxidant activities of tea powders were variable with the amount of tea powder. It was observed that antioxidant activity increased with increasing boiling time for smaller amount of sample. In contrary, shorter boiling time was better for larger amount of sample. The polyphenol contents of tea infusion were determined and the results were expressed as milligram quercetin equivalent $/ 200 \mathrm{~mL}$ of tea infusion. The polyphenol content was increased with increased brewing period. In contrary, brewing for longer time rendered extract less antiradical activity. This study suggests that infusing tea bag for 1 or $2 \mathrm{~min}$ is sufficient for getting infusion with maximum radical scavenging activity and in case of tea powder, shorter boiling time is better for larger amount of powder or small amount of powder should be boiled for minimum 5 min for rendering extract with maximum radical scavenging activity.
\end{abstract}

Keywords: tea bag, tea powder, antioxidants, polyphenols, 1,1-diphenyl-2-picrylhydrazyl radical

\section{Introduction}

Tea is an infusion of the leaves of the Camellia sinensis (Theaceae) plant. It is one of the most popular beverages in the world and currently revealed that it can promote health and helps to prevent a number of diseases (Arab et al., 2009; Peters et al., 2001). Tea is rich in flavonoids and other polyphenols known as catechins. The type of flavonoids found in different types of tea will depend on the level of processing the tea leaves. Depending on the manufacturing process, teas are classified into three major types, green tea non-fermented, oolong tea semifermented and black tea-fermented (Gupta et al., 2008; Zuo et al., 2002). During the oxidation process, enzymatic activity allows for the catechins to be polymerised and thus alter their structure. Typically, green tea leaves undergo minimal oxidation hence, retaining the majority of catechins. Black tea receives significant oxidation under controlled temperatures and humidity and results in the polymerisation of catechins into theaflavins and thearubigins. Theaflavins possess benzotropolone rings with dihydroxy or trihydroxy substitution systems which

*Author for correspondence; E-mail: nessa1995@yahoo.com give the characteristics colour and taste of the black tea (Menet et al., 2004). These catechins and their polymer can protect against heart disease and cancer (Higdon and Frei, 2003; Lambert and Yang, 2003; Vita, 2003; Yang and Landau, 2000; Lin et al., 1999; Buschman, 1998). Black tea extracts containing thearubigins, also effectively protect against the paralytic actions of botulinum neurotoxins (Satoh et al., 2001). Recently, reported green tea polyphenols exhibited beneficial effect on pathological states related to oxidative stress of the kidney (Yokozawa et al., 2012) and in oral health (Narotzki et al., 2012). The beneficial effects of tea are many, be ascribed to tea's antioxidant activity for their polyphenol contents. A number of studies reported that tea contained a number of polysaccharides which also exhibited good antioxidant activity (Wang et al., 2012; Xiao et al., 2011). However, the structural criteria of flavonoids for the potent free-radical scavengers are the presence of ortho-hydroxylation on the B-ring, a $\mathrm{C}_{2}-\mathrm{C}_{3}$ double bond in C-ring and the presence of 3-hydroxyl groups (Nessa et al., 2004; Bors et al., 1997; 1990; Rice-Evans et al., 1996). Levels of flavonoids in a tea brew will depend on many factors that include 
type of tea used or present in the tea bag as well as how long the tea is left to infuse in the water etc., (Peterson et al., 2004). Though, extensive work already done on the antioxidant potential of tea products (Nkubana and He, 2008; Su et al., 2007; Gramza et al., 2005; Cao et al., 1996), but very little information is available to study the free radical scavenging activity of tea infusion based on the brewing period. Therefore, the main aim of this research was to qualify the effectiveness of black, green and herbal tea infusion as the free radical scavengers based on the brewing period.

\section{Materials and Methods}

Samples. A set of 24 processed commercial tea products that includes: 8 black tea bag samples, 9 black tea powder samples, 5 green tea bag samples, 1 green tea powder sample and 1 herbal tea sample were purchased from the supermarket of Dubai, UAE during the September-October, 2011. The samples had been manufactured in different commercial factories using standard manufacturing conditions. The descriptions of samples are shown in the Table 1.

Table 1. Description of tea products

\begin{tabular}{|c|c|c|}
\hline Product & Manufacturer & Origin/country \\
\hline \multicolumn{3}{|l|}{ Black tea bags } \\
\hline Ahmed Tea London (English Tea No.1) & Packed in Sirlanka Ahmed Tea Limited & England (Sirlanka, India) \\
\hline Red Label (Brooke Bond) & Packed in UAE by Unilever Gulf FZE & India \\
\hline Lipton (Yellow Label Tea) & Packed in UAE by Unilever Gulf FZE & - \\
\hline Lulu (Blender's special) & Packed in UAE by Unilever Gulf FZE & India, Sirlanka, Africa \\
\hline Alokozay (Premium Tea) & Packed in UAE by Alokozay Tea International & Sirlanka \\
\hline Tetley London & Packed in India for Tetley GB Ltd & England \\
\hline (Drawstring Pure Black Tea) & TATA Tea Enterprise & \\
\hline Kanan devan (TATA Tea) & Packed \& Exported by TATA Tea Limited & India \\
\hline Premium (TATA Tea) & Packed \& Exported by TATA Tea Limited & India \\
\hline \multicolumn{3}{|l|}{ Black tea powder } \\
\hline Ahmed Tea London (English Tea No.1) & Packed in Sirlanka Ahmed Tea Limited & India \\
\hline Red Label (Brooke Bond) & Packed in UAE by Unilever Gulf FZE & - \\
\hline Lipton (Yellow Label Tea) & Packed in UAE by Unilever Gulf FZE & India, Sirlanka, Africa \\
\hline Lulu (Blender's special) & Packed in UAE by Unilever Gulf FZE & Srilanka \\
\hline Alokozay (Premium Tea) & Packed in UAE by Alokozay & Tea International Ltd., India \\
\hline Kanan Devan (TATA Tea) & Packed \& Exported by TATA Tea Limited & India \\
\hline Premium (TATA Tea) & Packed \& Exported by TATA Tea Limited & India \\
\hline Leone (Finest Indian Tea) & $\begin{array}{l}\text { Crown Oriental Food Ltd } \\
\text { Wembley Mildx HAO U.K }\end{array}$ & India \\
\hline $\begin{array}{l}\text { Society Tea (From the house of } \\
\text { Hasmukhxai \& Co) }\end{array}$ & Packed by Amerty privet Ltd & - \\
\hline \multicolumn{3}{|l|}{ Green tea bags } \\
\hline Twinings of London (Green Tea \& mint) & Packed R.Twining \& Company Limited & - \\
\hline Lipton (Clear Green) & Packed in UAE by Unilever Gulf FZE & England \\
\hline Tetley (Drawsting Pure Green Tea) & Packed in India for Tetley GB Ltd & Sirlanka \\
\hline $\begin{array}{l}\text { Alokozay (Premium Tea) Green Tea } \\
\text { Tea International Ltd., }\end{array}$ & Packed in UAE by Alokozay & Sirlanka - \\
\hline $\begin{array}{l}\text { Dilma (Special Green Tea } \\
\text { with natural Jasmine Petals) }\end{array}$ & Packed in Sirlanka Dilmah Australia Pty Ltd & UAE \\
\hline \multicolumn{3}{|l|}{ Green tea powder } \\
\hline Packed R.Twining \& Company Limited & Twining of London (Green Tea \& mint) & - \\
\hline \multicolumn{3}{|l|}{ Herbal tea product } \\
\hline Camomile Herbal Infusion (Safa) & Hassani Tea \& Herbs Factory, & UAE \\
\hline
\end{tabular}


Chemicals. 1,1-Diphenyl-2-picrylhydrazyl (DPPH) radical, quercetin, anhydrous sodium carbonate, FolinCiocalteu reagent, L-ascorbic acid, 1,1-diphenyl-2picrylhydrazyl, and methanol (spectroscopic grade) were purchased from Sigma Chemical Co. (USA).

Sample preparation. Tea infusions were prepared by infusing and steeping without stirring. For tea infusion, different tea bags were infused in $200 \mathrm{~mL}$ boiled distilled water at $120^{\circ} \mathrm{C}$ for 1,2 and $5 \mathrm{~min}$, respectively. The tea brew were prepared for tea powder, where different amounts of tea powder were boiled in $200 \mathrm{~mL}$ at $120{ }^{\circ} \mathrm{C}$ in a thermostatic hot plate for 1 and $5 \mathrm{~min}$, respectively. The tea infusion and brew was filtered through Whatman No. 1 filter paper, and brought at room temperature $\left(25^{\circ} \mathrm{C}\right)$. The aqueous tea filtrates were then immediately used for the determination of solid contents (yield), total polyphenolic contents and antioxidant activities.

Measurement of antioxidant activity. DPPH free radical scavenging method. The antioxidant activity of different aqueous tea extracts were evaluated using a stable radical, 1,1-diphenyl-2-picrylhydrazyl in a methanol solution according to the method of Nessa et al. (2004). Briefly, $100 \mu \mathrm{L}$ tea infusion solution was placed in a cuvette and $3.9 \mathrm{~mL}$ of $0.1 \mathrm{mM}$ methanolic solution of DPPH radical was added. The solution was incubated for $30 \mathrm{~min}$ at $25^{\circ} \mathrm{C}$ in dark and the absorbance was measured at $\lambda 517 \mathrm{~nm}$ with a Shimadzu-1700 uv-vis spectrophotometer. A blank sample (without tea infusion) containing methanolic DPPH radical was measured with the sample. All determinations were performed in three replicates. The percent inhibition of DPPH radical by the samples was calculated according to the formula, as follows:

$$
\% \text { inhibition }=\left[\left(\mathrm{A}_{\mathrm{C}(0)}-\mathrm{A}_{\mathrm{A}(\mathrm{t})}\right) / \mathrm{A}_{\mathrm{C}(0)}\right] \times 100
$$

where:

$A_{C(0)}$ is the absorbance of the control at $t=0$ min and $A_{A(t)}$ is the absorbance of the antioxidant at $t=30$ min.

A dose response curve was plotted for few selected tea products for studying hydrogen donating abilities of tea extracts. In this study, absorbance measurement commenced immediately. The decrease in absorbance at $\lambda 517 \mathrm{~nm}$ was determined continuously with data capturing at 2 min intervals until absorbance stabilised ( $\pm 30 \mathrm{~min})$. L-ascorbic acid was used as positive control.
Determination of total polyphenol content. Total polyphenolic contents were determined by the FolinCiocalteau method described by Scalbert et al. (1989). Folin Ciocalteu reagent was diluted (1:10) with distilled water. Briefly, the $100 \mu \mathrm{L}$ tea infusion/brewing solution (three replicates) were mixed with $2 \mathrm{~mL}$ diluted Folin Ciocalteu reagent and then $2 \mathrm{~mL}$ aqueous $\mathrm{Na}_{2} \mathrm{CO}_{3}$ (7.5\%). The mixture was allowed to stand for $1.5 \mathrm{~h}$ and the absorbance was measured at $\lambda 765 \mathrm{~nm}$ with a Shimadzu$1700 \mathrm{uv}$-vis spectrophotometer. The standard curve was prepared from $1-300 \mathrm{~g} / \mathrm{mL}$ solutions of quercetin in methanol: water $(80: 20, \mathrm{v} / \mathrm{v})$. The regression equation was $y=0.004 x+0.0166$ with regression coefficient (r) 0.999 . Total polyphenol values were expressed as milligram of quercetin equivalents per $200 \mathrm{~mL}$ of tea infusion.

\section{Results and Discussion}

Antioxidant activity of tea product infusion. Antioxidant activities of tea leaves infusion were determined according to the DPPH radical scavenging method. The DPPH radical has been widely used to test the free radical scavenging ability of various natural products (Sanchez-Moreno, 2002; Chen et al., 1999; Yamaguchi et al., 1998). According to this method, a compound with high antioxidant activity effectively binds with the radical hence, prevent its propagation and the resultant chain reaction. The results were expressed as mean \pm standard deviation (SD). The data of 1,2 and $5 \mathrm{~min}$ infusion of tea bags were compared for each product and were subjected to a one-way analysis of variance (ANOVA). Tukey's test $(\mathrm{P}<0.05)$ was performed to determine the significance of the difference between means.

Black tea bag products. Eight black tea bags and one herbal sample were infused for 1, 2 and $5 \mathrm{~min}$, respectively. For 1 min infusion, Tetley and Kanan Devan showed the highest free radical scavenging activity as decreased in the order of: Tetley $\geq$ Kanan Devan $>$ Lulu $>$ Alkozay $>$ Red Label $>$ Lipton $>$ Ahmed $>$ Camomile. In case of 2 min infusion, Lipton, Red Label and Kanan Devan exhibited highest free radical scavenging activity as decreased in the order of, Kanan Devan $\geq$ Lipton $\geq$ Red Label $\geq$ Lulu $>$ Tetley $>$ Ahmed $>$ Alkozay $>$ Tata $>$ Camomile. For 5 min infusion, Lipton, Red Label, Kanan Devan and Ahmed showed equal and highest free radical scavenging activity than other black tea bag products as decreased in the following order: Lipton $\geq$ Red Label $\geq$ Ahmed Kanan Devan $\geq$ Alkozoay $\geq$ 
Tetley $>$ Lulu $>$ Tata $>$ Camomile. Overall, Lipton, Red Label, Kanan Devan and Tetley showed the highest free radical scavenging activity and Camomile was the least free radical scavengers (Table 2). In comparison between 1, 2 and 5 min tea infusion for each product, overall 2 min tea infusion gave higher antioxidant activity than $1 \mathrm{~min}$. Tea infusion for $5 \mathrm{~min}$ gave lowest antioxidant activity except Ahmed tea bag, which gave higher antioxidant activity with increasing infusion time (5 $\mathrm{min}>2 \mathrm{~min}>1 \mathrm{~min}$ ) (Fig. 1). Amongst the studied black tea bag products Tata tea bag showed comparatively lower antioxidant activity than other tea products and showed highest antioxidant activity at 2 min infusion. But the mean differences were not significantly different $(\mathrm{P}<0.05)$ for Lulu $(1,2 \mathrm{~min})$, Lipton (2, 5 min), Red Label (2, 5 min), Tetly (1, 2 min), Kanan (1, 2, 5 min), Ahmed (2, 5 min) and Alkozay
(1, 5 min). Camomile, a herbal infusion showed lowest antioxidant activity and was significantly, lower than the other tea bag samples (Fig. 1). The antioxidant activity of tea infusion depends on many factors, one of these factor is the amount of leaves present in a tea bag (Peterson et al., 2004). All the studied black tea bags contained tea leaves in the ranges of 2.03 to $2.68 \mathrm{~g}$ except Camomile herbal tea which contained about $0.95 \mathrm{~g}$ leaves in a bag. It seems the lowest antioxidant activity of Camomile was due to the lower amount of leaves present in the tea bag. From the results it was concluded that brewing the black tea bags for 1 to 2 min was sufficient to obtain higher antioxidant activity.

Green tea bag products. Five tea bag samples were infused for 1 and $5 \mathrm{~min}$ for determination of their free

Table 2. Free radical scavenging activity and total polyphenol concentration of tea infusion of different black tea bag samples. Results are mean $\pm \mathrm{SD}(n=3)$

\begin{tabular}{|c|c|c|c|c|c|}
\hline Products & $\begin{array}{l}\text { Av. wt. of } \\
\text { tea leaves/bag } \\
\text { (g) }\end{array}$ & $\begin{array}{l}\text { Brewing } \\
\text { period } \\
(\mathrm{min})\end{array}$ & $\begin{array}{l}\text { Solid } \\
\text { contents } \\
(\mathrm{mg} / \mathrm{mL})\end{array}$ & $\begin{array}{l}\text { Scavenging of } \\
\mathrm{DPPH}^{\bullet} \\
(\% \pm \mathrm{SD})\end{array}$ & $\begin{array}{l}\text { Polyphenol } / 200 \mathrm{~mL} \\
\text { products tea infusion } \\
(\mathrm{mg} \pm \mathrm{SD})\end{array}$ \\
\hline \multirow[t]{3}{*}{ Lulu } & \multirow[t]{3}{*}{2.04} & 1 & 2.01 & $88.64 \pm 0.50$ & $35.13 \pm 1.95$ \\
\hline & & 2 & 2.98 & $88.50 \pm 0.77$ & $73.14 \pm 1.35$ \\
\hline & & 5 & 3.98 & $86.49 \pm 0.33$ & $124.25 \pm 2.55$ \\
\hline \multirow[t]{3}{*}{ Lipton } & \multirow[t]{3}{*}{2.07} & 1 & 2.21 & $82.18 \pm 0.66$ & $30.51 \pm 1.47$ \\
\hline & & 2 & 3.13 & $90 \pm 0.55$ & $49.82 \pm 1.65$ \\
\hline & & 5 & 4.29 & $88.9 \pm 0.43$ & $156.2 \pm 2.41$ \\
\hline \multirow[t]{3}{*}{ Tata } & \multirow[t]{3}{*}{2.03} & 1 & 1.76 & $78.44 \pm 0.11$ & $59.84 \pm 1.28$ \\
\hline & & 2 & 2.44 & $82.90 \pm 0.88$ & $82.14 \pm 2.72$ \\
\hline & & 5 & 4.01 & $80.17 \pm 0.67$ & $122.25 \pm 1.25$ \\
\hline \multirow[t]{3}{*}{ Red Label } & \multirow[t]{3}{*}{2.07} & 1 & 2.4 & $84.77 \pm 0.50$ & $24.64 \pm 1.99$ \\
\hline & & 2 & 3.78 & $89.94 \pm 0.66$ & $66.49 \pm 0.91$ \\
\hline & & 5 & 4.35 & $88.64 \pm 0.88$ & $103.34 \pm 1.25$ \\
\hline \multirow[t]{3}{*}{ Tetley } & \multirow[t]{3}{*}{2.68} & 1 & 2.36 & $89.79 \pm 0.99$ & $75.22 \pm 0.95$ \\
\hline & & 2 & 3.69 & $88.79 \pm 0.32$ & $106.75 \pm 1.14$ \\
\hline & & 5 & 4.43 & $87.06 \pm 0.58$ & $209.47 \pm 0.75$ \\
\hline \multirow[t]{3}{*}{ Kanan Devan } & \multirow[t]{3}{*}{2.07} & 1 & 1.72 & $89.94 \pm 0.34$ & $46.37 \pm 1.16$ \\
\hline & & 2 & 2.39 & $90.51 \pm 0.88$ & $78.4 \pm 1.23$ \\
\hline & & 5 & 3.87 & $88.21 \pm 0.95$ & $121.25 \pm 1.35$ \\
\hline \multirow[t]{3}{*}{ Ahmed } & \multirow[t]{3}{*}{2.06} & 1 & 1.74 & $67.81 \pm 0.54$ & $21.43 \pm 1.15$ \\
\hline & & 2 & 2.01 & $87.5 \pm 0.56$ & $77.68 \pm 1.12$ \\
\hline & & 5 & 3.66 & $88.6 \pm 0.37$ & $133.52 \pm 1.50$ \\
\hline \multirow[t]{3}{*}{ Alkozay } & \multirow[t]{3}{*}{2.06} & 1 & 1.50 & $86.06 \pm 0.66$ & $29.69 \pm 1.77$ \\
\hline & & 2 & 2.41 & $85.63 \pm 0.44$ & $74.5 \pm 1.11$ \\
\hline & & 5 & 3.33 & $87.35 \pm 0.79$ & $139.68 \pm 0.94$ \\
\hline
\end{tabular}


radical scavenging capacity (Table 3 ). All products exhibited in the ranges of $90.37-94.51 \%$ free radical scavenging activity as long as it brewed. In comparison between 1 min infusion of green tea bag samples, Tetley tea bag showed highest antioxidant activity than other studied samples as decreased in the order of: Tetley $>$ Dilma $\geq$ Lipton $>$ Alkozay $>$ Twinings. For $5 \mathrm{~min}$ infusion, the antioxidant activity decreased in the order of: Lipton $>$ Dilma $>$ Alkozay $>$ Tetley $>$ Twinings (Fig. 1). But the mean differences between 1,2 and 5 min infusion were not statistically significant $(P>0.05)$. It seemed 1 min infusion was enough to get maximum antioxidant activity and infusion for longer time did not significantly increase or decrease the antioxidant activity. The detailed analytical value for all studied tea bag herbal products are tabulated in Table 2-3.

Black and green tea powder products. In this study, 9 black tea powders and one green tea powder samples were analysed. Four different amounts $(0.1 \mathrm{~g}, 0.5 \mathrm{~g}$, $1.0 \mathrm{~g}$ and $2.0 \mathrm{~g}$ ) of tea leaves powder for each product were boiled for 1 min and 5 min separately (Fig. 2). For 1 min infusion of all samples, the free radical scavenging activity significantly $(\mathrm{P}>0.05)$, increased

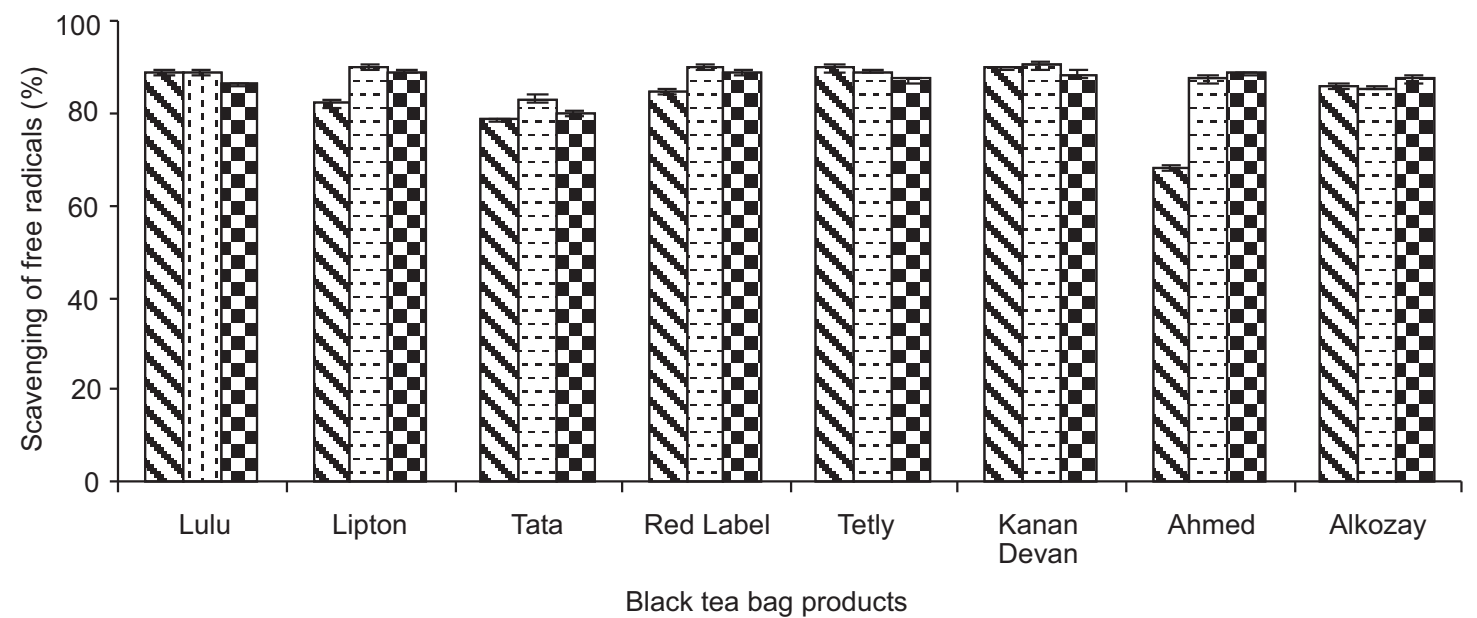

$\mathbf{0} 1 \mathrm{~min} \quad \mathbf{2} 2 \mathrm{~min} \quad \square \mathrm{min}$

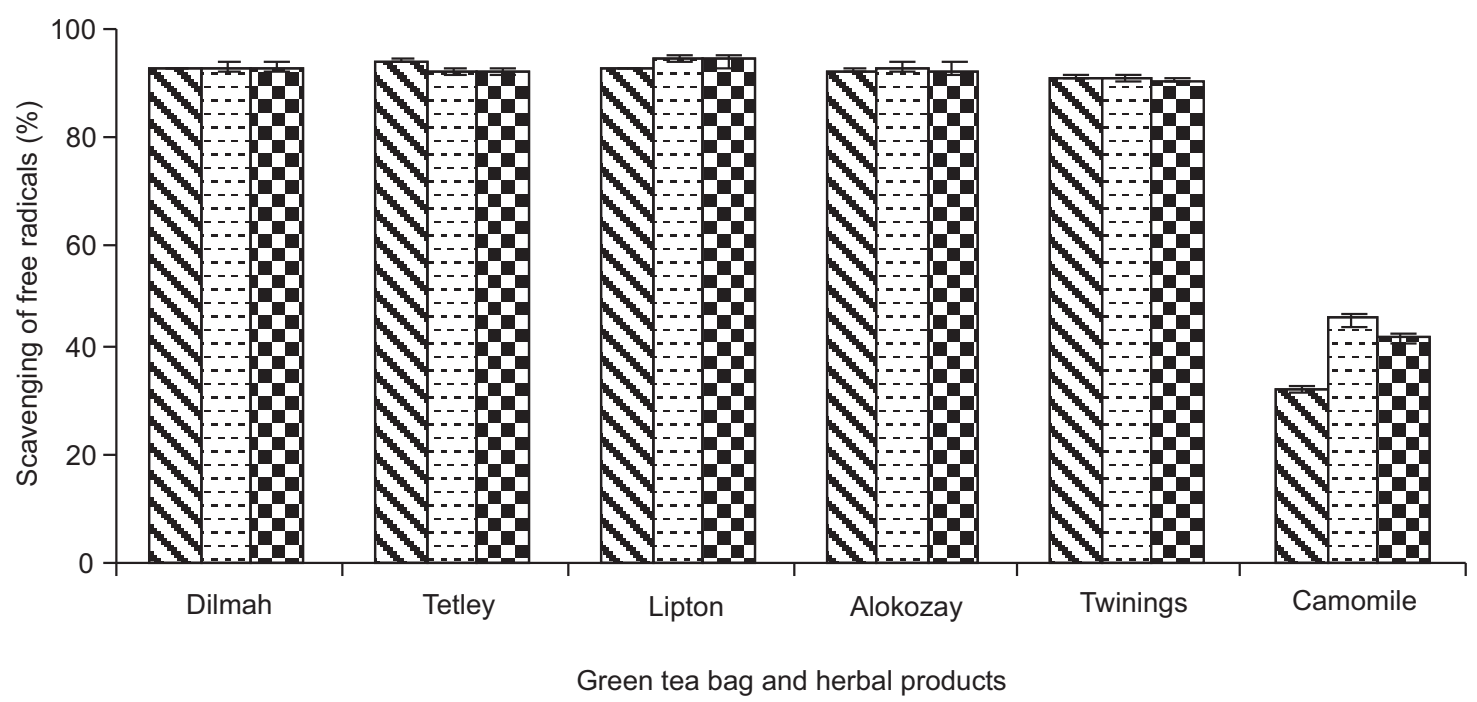

12 min $\quad 02$ min 5 min

Fig. 1. Free radical scavenging activity of different manufacturer's tea bags (black, green and herbal) samples measured using the DPPH assay. Results are mean $\pm \mathrm{SD}(n=3)$. 
with increasing the amount of samples. For $5 \mathrm{~min}$ infusion, free radical scavenging activity only increased for 0.1 and $0.5 \mathrm{~g}$ samples but in contrary, decreased for 1.0 and $2.0 \mathrm{~g}$ samples with increasing boiling period from $1 \mathrm{~min}$ to $5 \mathrm{~min}$ (Table 4-5). It seems shorter brewing period was better for larger amount of powder, in contrary, longer brewing period was necessary for brewing smaller amount of tea powder for getting higher antioxidant activity.
For a few selected tea samples the rate of reaction with the free radicals was also evaluated. In dose response studies it was found that tea infusion scavenged the free radicals very fast as it can be seen in Fig. 3-4 and reached a steady state within $5 \mathrm{~min}$. Camomile, a herbal sample very slowly scavenged free radicals as compared to Lipton tea samples (Fig. 3B). In comparison of green tea with black tea bag samples, black tea scavenged free radicals comparatively slowly than green tea bag

A. Tea powder products (brewed for $1 \mathrm{~min}$ )

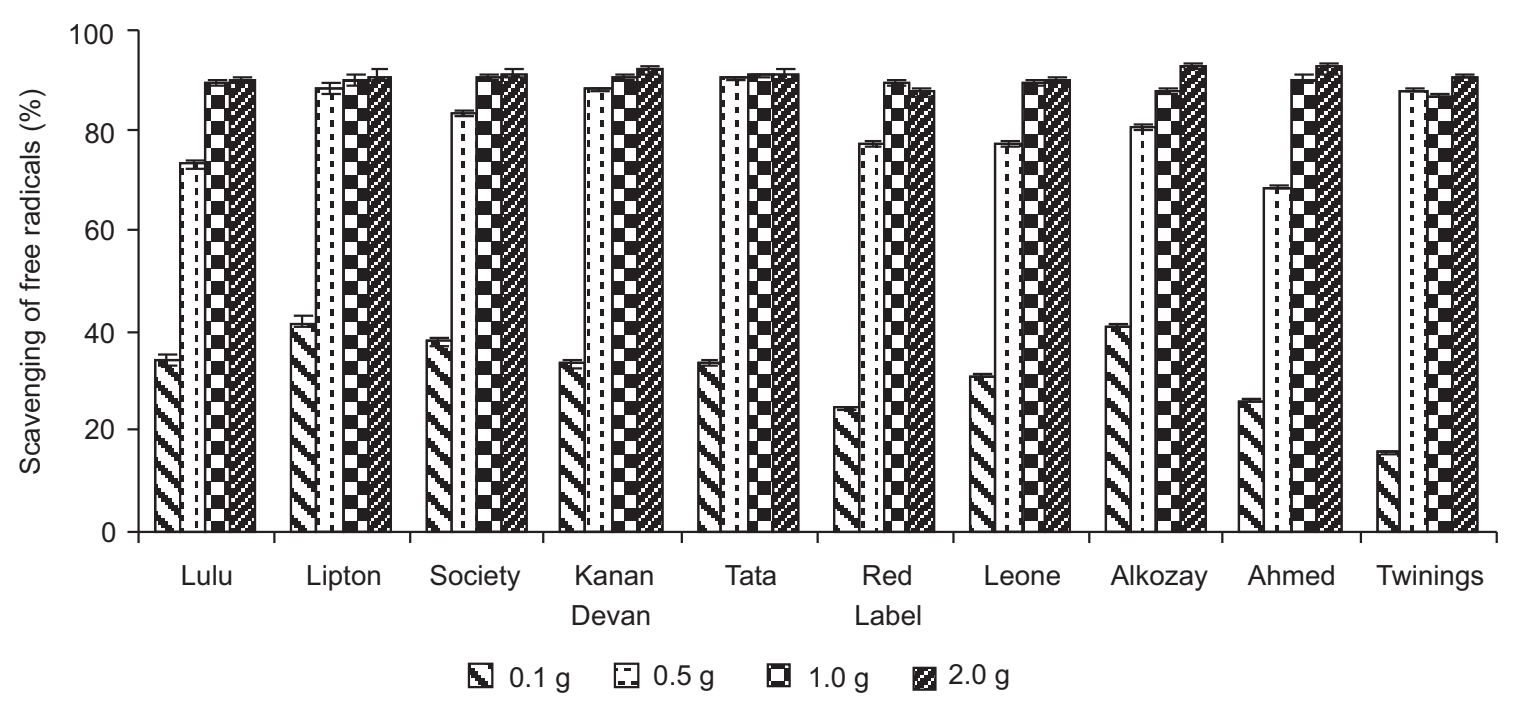

B. Tea powder product (brewed for $5 \mathrm{~min}$ )

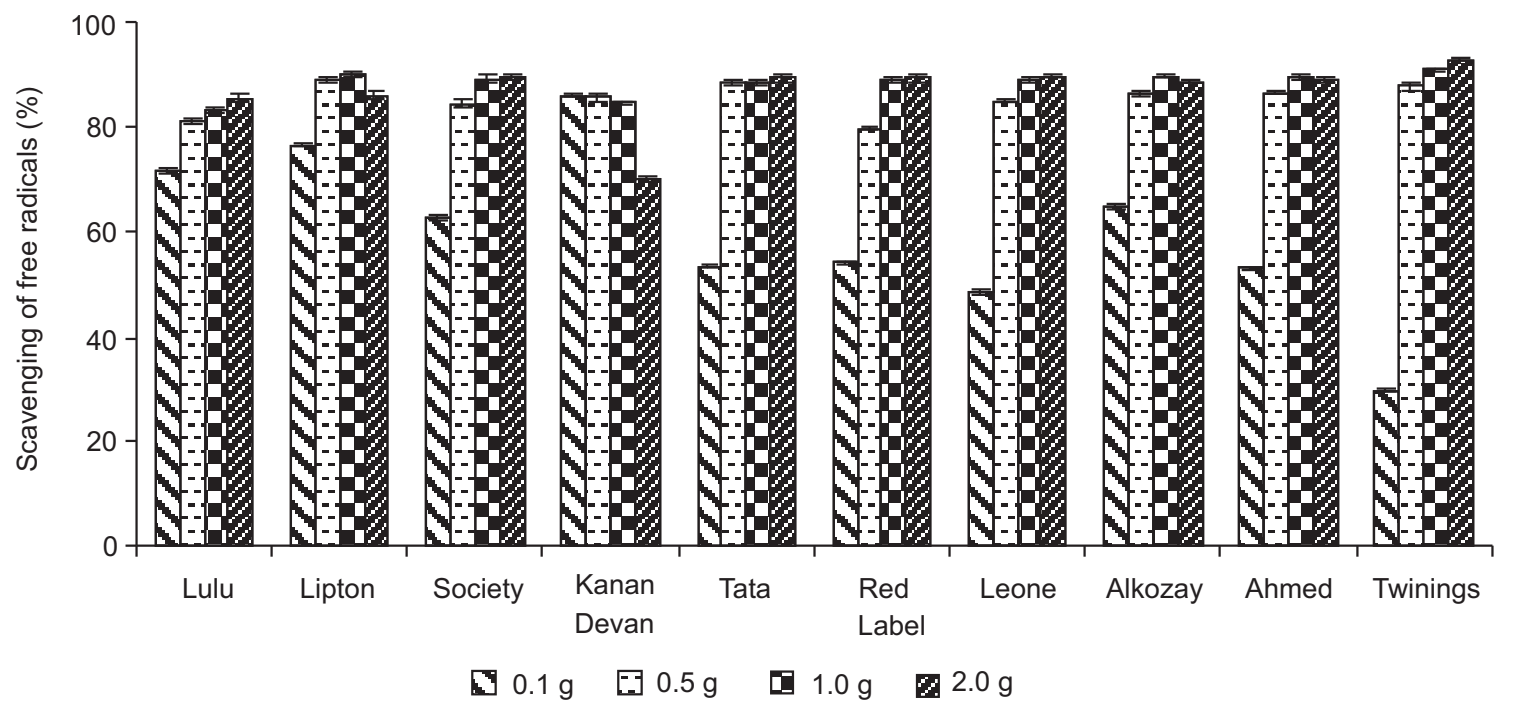

Fig. 2. Free radical scavenging activities of tea infusion prepared from different amount of tea powder leaves $v s$. the scavenging of free radicals, measured using the DPPH assay. Results are mean $\pm \mathrm{SD}(n=3)$. Samples were brewed for $1 \mathrm{~min}(\mathrm{~A})$ and $5 \mathrm{~min}(\mathrm{~B})$. 
Table 3. Free radical scavenging activity and total polyphenol concentration of tea infusion of different green tea bag/herbal samples. Results are mean $\operatorname{SD}(n=3)$

\begin{tabular}{|c|c|c|c|c|c|}
\hline Products & $\begin{array}{l}\text { Av. wt. of } \\
\text { tea leaves/bag } \\
(\mathrm{g})\end{array}$ & $\begin{array}{l}\text { Brewing } \\
\text { contents } \\
(\mathrm{min})\end{array}$ & $\begin{array}{l}\text { Solid } \\
\text { period } \\
(\mathrm{mg} / \mathrm{mL})\end{array}$ & $\begin{array}{l}\text { Scavenging of } \\
\mathrm{DPPH}^{\bullet} \\
(\% \pm \mathrm{SD})\end{array}$ & $\begin{array}{l}\text { Polyphenol } / 200 \mathrm{~mL} \\
\text { products tea infusion } \\
(\mathrm{mg} \pm \mathrm{SD})\end{array}$ \\
\hline \multirow[t]{3}{*}{ Dilma } & \multirow[t]{3}{*}{2.11} & 1 & 1.82 & $93.11 \pm 0.32$ & $41.49 \pm 1.05$ \\
\hline & & 2 & 2.99 & $93.32 \pm 0.73$ & $86.45 \pm 0.95$ \\
\hline & & 5 & 3.53 & $93.32 \pm 0.92$ & $137.55 \pm 1.11$ \\
\hline \multirow[t]{3}{*}{ Tetley } & \multirow[t]{3}{*}{2.16} & 1 & 1.43 & $94.07 \pm 0.34$ & $63.17 \pm 0.96$ \\
\hline & & 2 & 3.11 & $92.46 \pm 0.73$ & $95.23 \pm 1.26$ \\
\hline & & 5 & 3.92 & $92.46 \pm 0.63$ & $165.50 \pm 1.84$ \\
\hline \multirow[t]{3}{*}{ Lipton } & \multirow[t]{3}{*}{1.54} & 1 & 1.52 & $93.11 \pm 0.25$ & $64.65 \pm 0.60$ \\
\hline & & 2 & 3.04 & $94.51 \pm 0.62$ & $72.67 \pm 0.60$ \\
\hline & & 5 & 3.68 & $94.51 \pm 0.83$ & $92.23 \pm 1.63$ \\
\hline \multirow[t]{3}{*}{ Alkozay } & \multirow[t]{3}{*}{1.95} & 1 & 1.90 & $92.68 \pm 0.25$ & $68.33 \pm 2.45$ \\
\hline & & 2 & 3.16 & $92.89 \pm 0.62$ & $89.34 \pm 1.60$ \\
\hline & & 5 & 4.01 & $92.89 \pm 0.15$ & $164.57 \pm 0.73$ \\
\hline \multirow[t]{3}{*}{ Twinings } & \multirow[t]{3}{*}{2.04} & 1 & 1.31 & $91.09 \pm 0.45$ & $140.85 \pm 2.62$ \\
\hline & & 2 & 2.97 & $90.94 \pm 0.74$ & $158.65 \pm 2.62$ \\
\hline & & 5 & 3.65 & $90.37 \pm 0.31$ & $171.85 \pm 1.21$ \\
\hline \multirow[t]{3}{*}{ Camomile } & \multirow[t]{3}{*}{0.95} & 1 & 0.99 & $32.90 \pm 0.73$ & $62.17 \pm 1.89$ \\
\hline & & 2 & 1.34 & $45.54 \pm 0.92$ & $61.46 \pm 1.39$ \\
\hline & & 5 & 2.44 & $42.09 \pm 0.87$ & $63.2 \pm 1.27$ \\
\hline
\end{tabular}

infusion, but after 5 min there were no significant differences in their scavenging activities (Fig. 3A). In dose-response studies of tea power $(2.0 \mathrm{~g})$ and tea bag $(2.04 \mathrm{~g})$, infusion of tea bag scavenged free radicals comparatively little faster than the powder leaves infusion as it can be depicted from the Fig. 4. In doseresponse studies, L-ascorbic acid was used as a reference standard and reacted with DPPH immediately and reached a steady state within a minute (Nessa et al., 2004). Its scavenging capability was rapid and dependent on concentration/dose (Fig. 3B). In this study, all the studied tea infusions also reacted rapidly with DPPH radical and reached a steady state within 2 to $5 \mathrm{~min}$. It seemed tea infusion also acted as fast free radical scavenger as ascorbic acid.

The total polyphenols content of tea bag and tea powder products. Free radical scavenging activity of tea extracts depends mainly on its polyphenolic content (Gupta et al., 2008; Higdon and Frei, 2003; Yang and Landau, 2000). Therefore, the polyphenolic contents of all studied tea products were determined and the results were expressed as milligram quercetin equivalent/ $200 \mathrm{~mL}$ of tea infusion. The results are presented in
Table 2-5. In case of black and green tea bags, the polyphenolic content increased with increasing brewing time from $1 \mathrm{~min}$ to $5 \mathrm{~min}$. In comparison amongst 1 min infusion of black tea bag samples, lowest concentration was recorded in Ahmed tea bag (21.43 \pm 1.15 ) and highest amount recorded in Tetly tea bag (75.22 - 0.95). The overall results were decreased in the order of: Tetly $>$ Tata $>$ Kanan Devan $>$ Lulu $>$ Lipton $\geq$ Alkozay $>$ Red Label $>$ Ahmed. In case of 2 min infusion, highest concentration was recorded in Tetly tea bag $(106.75 \pm 1.14)$ and the results decreased in the order of: Tetly $>$ Tata $>$ Ahmed $\geq$ Kanan Devan $>$ Alkozay $>$ Lulu $>$ Red Label $>$ Lipton. For 5 min infusion, the lowest amount recorded in Red Label $(103.34 \pm 1.25)$ and the results decreased in the order of: Tetly $>$ Lipton $>$ Alkozay $>$ Ahmed $>$ Lulu $>$ Tata $>$ Kanan Devan $>$ Red Label. However, Tetley exhibited highest polyphenolic content amongst the studied tea bag samples, in contrary, the polyphenolic content of Camomile (a herbal infusion) was not increased with increasing infusion time and the values were in the ranges of $61.24 \mathrm{mg}$ to $63.2 \mathrm{mg}$. The polyphenolic content of all studied black tea bag samples are tabulated in Table 2. 

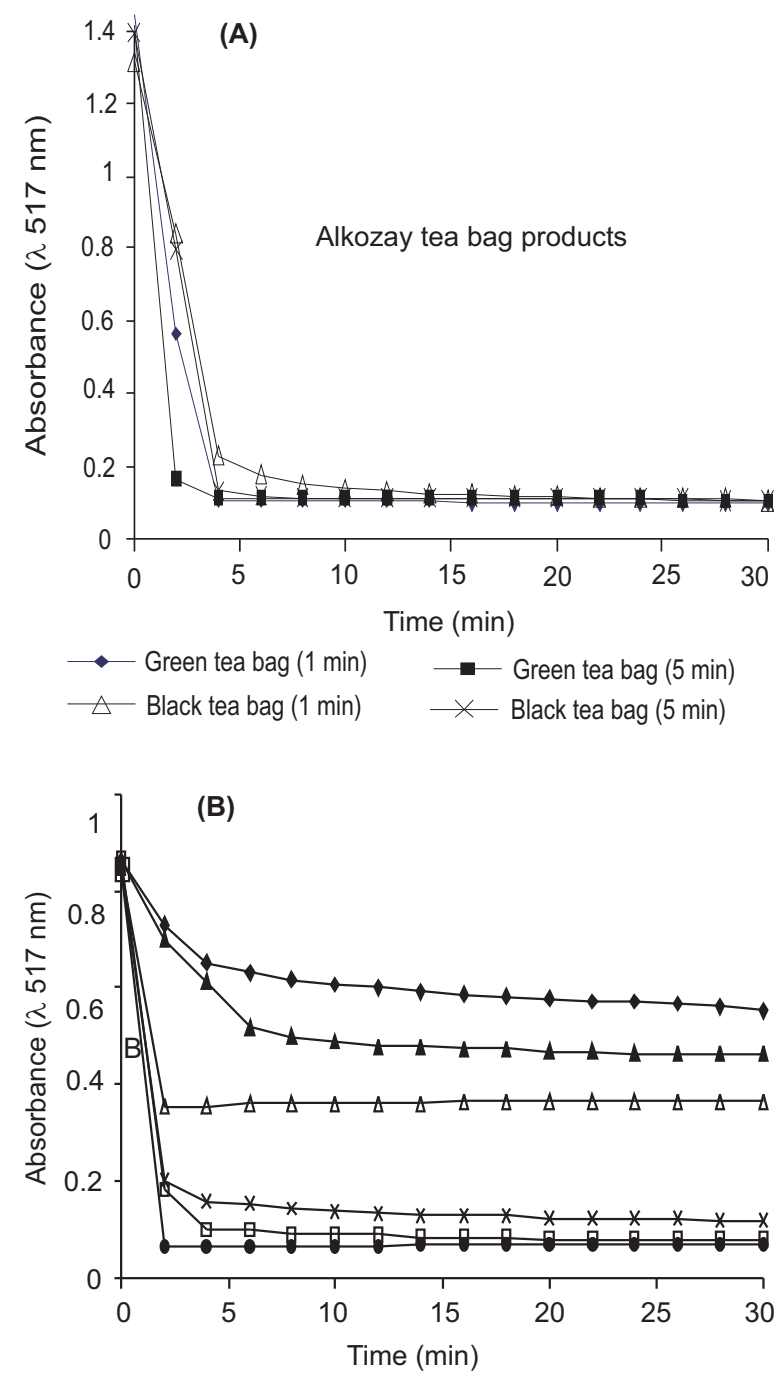

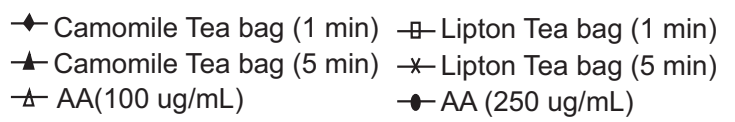

Fig. 3. Hydrogen donating abilities of Alkozay tea bag products (A) Camomile, Lipton tea bag products and Ascorbic acid (AA, 100 and $250 \mu \mathrm{g} / \mathrm{mL}$ ) (B) on 1,1-diphenyl-2picrylhydrazyl (DPPH) radical.

For green tea bag samples, 5 min infusion exhibited higher concentration of polyphenols than $1 \mathrm{~min}$ infusion. Dilma tea bag showed lowest polyphenol content $(41.49 \mathrm{mg}$ ) for $1 \mathrm{~min}$ infusion and Twinings exhibited highest content about $140.85 \mathrm{mg}$. For $5 \mathrm{~min}$ infusion, again Twinings showed highest polyphenol content $(171.85 \mathrm{mg})$ and lowest amount recorded in Tetley (63.17 mg). Though, polyphenol content of all tea bag samples increased with increasing infusion time but in
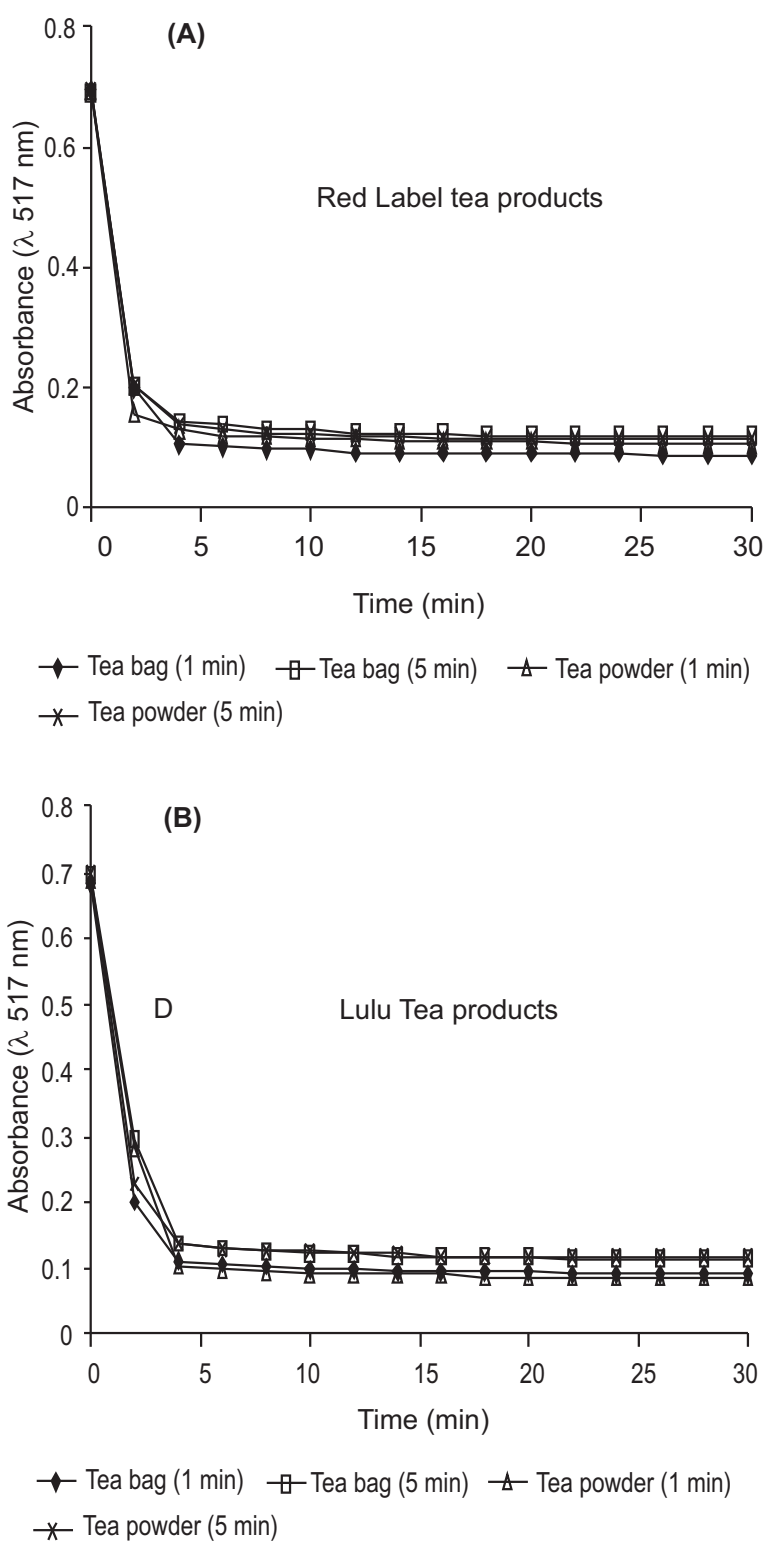

Fig. 4. Hydrogen donating abilities of Red Label tea products (A) and Lulu tea products (B) on 1,1-diphenyl-2-picrylhydrazyl (DPPH) radical.

contrary, DPPH radical scavenging activity was not increased with increasing polyphenol content. Though polyphenol content of Dilma was lower for $1 \mathrm{~min}$ infusion than $5 \mathrm{~min}$, but both infusions scavenged free radicals effectively. Other studied green tea bag samples also exhibited similar results, as it can be depicted from Table 3. It seems that some other chemical compounds such as tannin extracted at longer boiling time, which might interfered the free radical scavenging 
Table 4. Free radical scavenging activity and total polyphenol concentration of infusion of tea leaves powder samples (Lulu, Lipton, Society, Kanan Devan, Tata and Red Label). Results are mean SD $(n=3)$

\begin{tabular}{|c|c|c|c|c|c|}
\hline \multirow{3}{*}{$\begin{array}{l}\text { Tea product } \\
\text { (powder) }\end{array}$} & \multirow{3}{*}{$\begin{array}{l}\text { Wt. of tea } \\
\text { powder } \\
(\mathrm{g})\end{array}$} & \multicolumn{4}{|c|}{ Brewing period } \\
\hline & & \multicolumn{2}{|c|}{$(1 \mathrm{~min})$} & \multicolumn{2}{|c|}{$(5 \mathrm{~min})$} \\
\hline & & $\begin{array}{l}\text { Scavenging } \\
\text { of DPPH } \\
(\% \pm \mathrm{SD})\end{array}$ & $\begin{array}{l}\text { Polyphenol } \\
\mathrm{mg} / 200 \mathrm{~mL} \\
\text { tea infusion }\end{array}$ & $\begin{array}{l}\text { Scavenging of } \\
\text { DPPH }^{\bullet} \\
(\% \pm \mathrm{SD})\end{array}$ & $\begin{array}{l}\text { Polyphenol } \\
\mathrm{mg} / 200 \mathrm{~mL} \\
\text { tea infusion }\end{array}$ \\
\hline \multirow[t]{4}{*}{ Lulu } & 0.1032 & $34.19 \pm 0.97$ & $2.94 \pm 0.52$ & $71.79 \pm 0.33$ & $7.94 \pm 1.05$ \\
\hline & 0.5012 & $73.24 \pm 0.87$ & $26.26 \pm 2.09$ & $81.05 \pm 0.51$ & $34.57 \pm 1.06$ \\
\hline & 1.023 & $89.47 \pm 0.56$ & $58.06 \pm 1.59$ & $83.33 \pm 0.45$ & $83.03 \pm 1.50$ \\
\hline & 2.012 & $90.32 \pm 0.57$ & $86.2 \pm 1.42$ & $85.75 \pm 0.73$ & $155.83 \pm 1.71$ \\
\hline \multirow[t]{4}{*}{ Lipton } & 0.1002 & $41.83 \pm 0.89$ & $0.29 \pm 0.16$ & $76.43 \pm 0.38$ & $4.06 \pm 0.49$ \\
\hline & 0.5015 & $88.33 \pm 1.22$ & $23.34 \pm 2.00$ & $89.04 \pm 0.57$ & $39.62 \pm 1.11$ \\
\hline & 1.011 & $90.06 \pm 0.99$ & $58.16 \pm 1.03$ & $89.90 \pm 0.59$ & $104.90 \pm 1.41$ \\
\hline & 2.015 & $90.86 \pm 0.89$ & $175.36 \pm 1.87$ & $86.35 \pm 0.91$ & $116.99 \pm 1.56$ \\
\hline \multirow[t]{4}{*}{ Society } & 0.1012 & $37.87 \pm 0.78$ & $5.15 \pm 0.06$ & $63.08 \pm 0.51$ & $8.68 \pm 0.89$ \\
\hline & 0.5011 & $83.49 \pm 0.56$ & $30.47 \pm 0.99$ & $84.77 \pm 0.69$ & $48.43 \pm 1.00$ \\
\hline & 1.014 & $90.61 \pm 0.45$ & $77.79 \pm 0.63$ & $89.06 \pm 0.81$ & $103.73 \pm 1.62$ \\
\hline & 2.005 & $91.21 \pm 0.55$ & $107.03 \pm 0.93$ & $89.47 \pm 0.57$ & $166.99 \pm 1.56$ \\
\hline \multirow[t]{4}{*}{ Kanan Devan } & 0.1000 & $33.24 \pm 0.64$ & $8.73 \pm 0.76$ & $86.36 \pm 0.44$ & $9.48 \pm 0.83$ \\
\hline & 0.5024 & $88.31 \pm 0.16$ & $20.79 \pm 1.67$ & $85.97 \pm 0.65$ & $41.94 \pm 1.27$ \\
\hline & 1.024 & $90.61 \pm 0.65$ & $46.51 \pm 1.04$ & $84.90 \pm 0.38$ & $104.51 \pm 1.03$ \\
\hline & 2.055 & $91.71 \pm 0.54$ & $89.53 \pm 1.12$ & $70.21 \pm 0.49$ & $145.43 \pm 1.02$ \\
\hline \multirow[t]{4}{*}{ Tata } & 0.1004 & $33.51 \pm 0.39$ & $11.55 \pm 1.08$ & $53.13 \pm 0.33$ & $8.92 \pm 0.96$ \\
\hline & 0.5025 & $90.61 \pm 0.19$ & $29.36 \pm 1.64$ & $88.47 \pm 0.41$ & $41.24 \pm 1.50$ \\
\hline & 1.014 & $91.18 \pm 0.43$ & $62.51 \pm 2.02$ & $88.33 \pm 0.49$ & $105.85 \pm 1.13$ \\
\hline & 2.013 & $91.09 \pm 0.81$ & $185.36 \pm 1.87$ & $89.36 \pm 0.71$ & $93.72 \pm 1.61$ \\
\hline \multirow[t]{4}{*}{ Red Label } & 0.1011 & $24.66 \pm 0.22$ & $2.38 \pm 1.30$ & $53.95 \pm 0.36$ & $14.5 \pm 0.93$ \\
\hline & 0.5021 & $77.38 \pm 0.43$ & $19.29 \pm 1.84$ & $79.8 \pm 0.48$ & $43.81 \pm 1.69$ \\
\hline & 1.004 & $89.61 \pm 0.35$ & $40.52 \pm 1.78$ & $89.04 \pm 0.39$ & $93.29 \pm 0.87$ \\
\hline & 2.015 & $87.63 \pm 0.73$ & $170.75 \pm 2.56$ & $89.36 \pm 0.71$ & $101.58 \pm 2.46$ \\
\hline
\end{tabular}

activity as it can be observed from the appearance of tea infusion. The appearance of $1 \mathrm{~min}$ infused tea was clear in colour and 5 min infused tea was cloudy and turbidity appeared upon standing as it contained more solids. The solid contents of tea infusion were higher in $5 \mathrm{~min}$ infused/brewed tea than $1 \mathrm{~min}$ and the values are tabulated in Table 2-3.

For black and green tea powder brew, when lower amount of tea leaves powder $(0.1 \mathrm{~g})$ boiled for $1 \mathrm{~min}$ produced infusion with lower polyphenol content, on the other hand when same quantity $(0.1 \mathrm{~g})$ boiled for 5 min produced infusion having higher polyphenol contents. Similarly, tea brew prepared with increasing the quantity of tea leaves powder from $1.0 \mathrm{~g}$ to $2.0 \mathrm{~g}$, $2.0 \mathrm{~g}$ of tea leaves powder produced infusion with higher polyphenol contents than $1.0 \mathrm{~g}$ powder. From this study, it was clear that the polyphenol contents of tea leaves powder products increased with increasing infusion/ steeping time as well as with increasing the amount of tea leaves powder (Fig. 5). Table 4-5 represents the total polyphenol contents of all studied tea powder samples.

Correlation between DPPH radical scavenging activity of black tea leaves powder and their polyphenol content by linear regression analysis was also evaluated and correlation coefficients values were decreased for $1 \mathrm{~min}$ infusion in the order of: Lulu (0.7883) $>$ Ahmed $(0.7755)$ $>$ Alkozay $(0.7152)>$ Society $(0.6543)>$ Leone $(0.4599)$ $>$ Kanan Devan (0.4164) > Twinings $(0.3365)>$ Lipton $(0.3365)>$ Red Label $(0.3049)>$ Tata $(0.2705)$; and for 5 min infusion in the order of: Red Label $(0.8499)>$ Lulu (0.7201) > Alkozay (0.6697) > Kanan Devan 


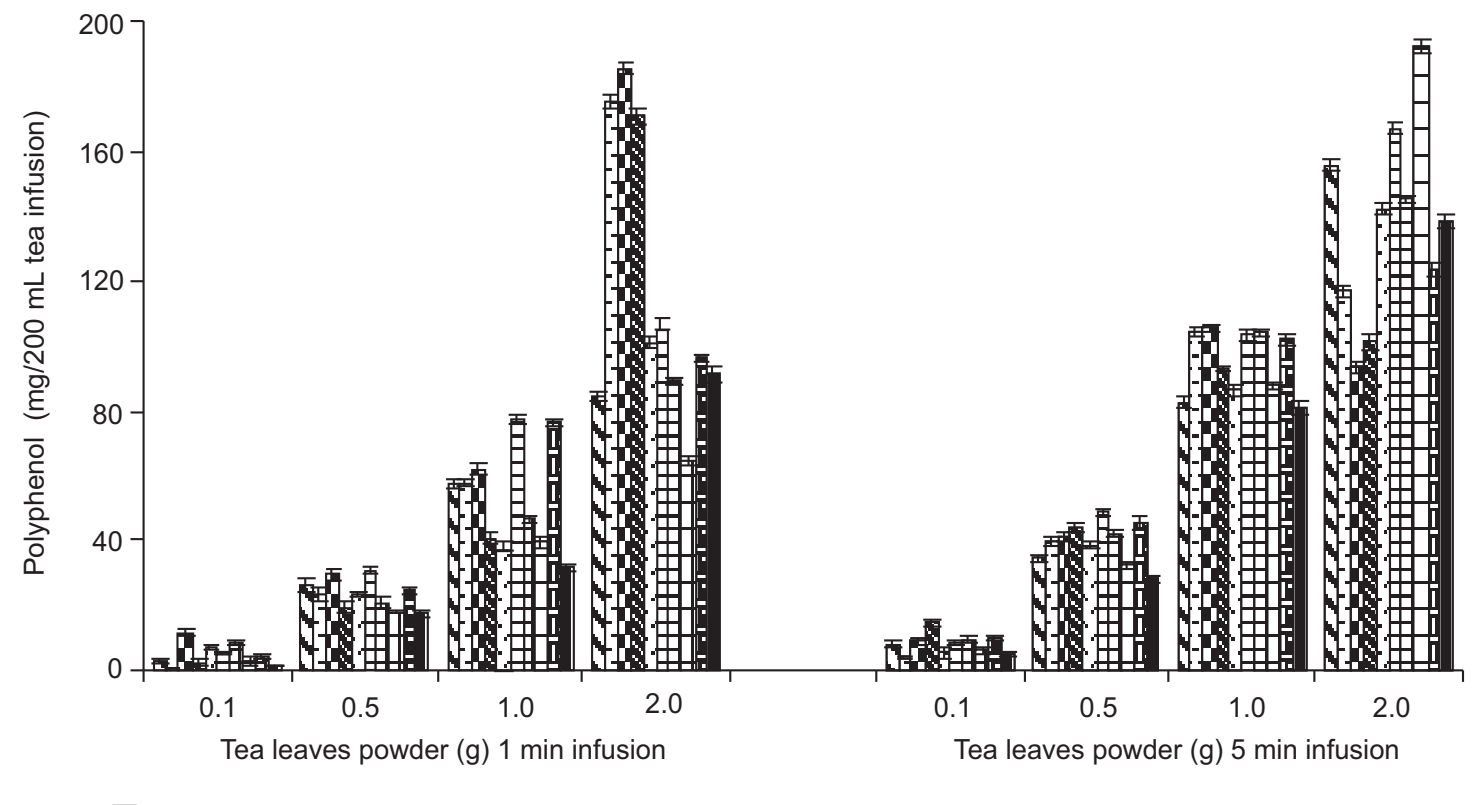

Lulu $\because$ Tata $\square$ Leone Kanan $\because$ Alkozay $\boxminus$ Lipton $\boxplus$ Red label $\boxminus$ Society 담 Ahmed II Twinings

Fig. 5. Total polyphenol concentration of black tea and green tea leaves powder products boiled in $200 \mathrm{~mL}$ distilled water for 1 and $5 \mathrm{~min}$. Results are mean $\pm \mathrm{SD}(n=3)$.

Table 5. Free radical scavenging activity and total polyphenol concentration of infusion of tea leaves powder samples (Leone, Alkozay, Ahmed and Twinings). Results are mean $\mathrm{SD}(n=3)$

\begin{tabular}{|c|c|c|c|c|c|}
\hline \multirow{3}{*}{$\begin{array}{l}\text { Tea product } \\
\text { (powder) }\end{array}$} & \multirow{3}{*}{$\begin{array}{l}\text { Wt. of tea } \\
\text { powder } \\
\text { (g) }\end{array}$} & \multicolumn{4}{|c|}{ Brewing period } \\
\hline & & \multicolumn{2}{|c|}{$(1 \mathrm{~min})$} & \multicolumn{2}{|c|}{$(5 \mathrm{~min})$} \\
\hline & & $\begin{array}{l}\text { Scavenging } \\
\text { of DPPH }^{\bullet} \\
(\% \pm \mathrm{SD})\end{array}$ & $\begin{array}{l}\text { Polyphenol } \\
\mathrm{mg} / 200 \mathrm{~mL} \\
\text { tea infusion }\end{array}$ & $\begin{array}{l}\text { Scavenging of } \\
\mathrm{DPPH}^{\bullet} \\
(\% \pm \mathrm{SD})\end{array}$ & $\begin{array}{l}\text { Polyphenol } \\
\mathrm{mg} / 200 \mathrm{~mL} \\
\text { tea infusion }\end{array}$ \\
\hline \multirow[t]{4}{*}{ Leone } & 0.1001 & $30.65 \pm 0.28$ & $7.37 \pm 0.06$ & $48.50 \pm 0.63$ & $5.47 \pm 0.89$ \\
\hline & 0.5001 & $77.52 \pm 0.39$ & $23.34 \pm 0.99$ & $85.34 \pm 0.43$ & $38.51 \pm 1.85$ \\
\hline & 1.008 & $89.61 \pm 0.51$ & $38.11 \pm 1.63$ & $89.04 \pm 0.55$ & $86.73 \pm 1.72$ \\
\hline & 2.005 & $90.40 \pm 0.53$ & $101.75 \pm 1.93$ & $89.59 \pm 0.32$ & $142.35 \pm 1.88$ \\
\hline \multirow[t]{4}{*}{ Alkozay } & 0.1018 & $41.28 \pm 0.38$ & $4.01 \pm 0.59$ & $64.58 \pm 0.63$ & $9.94 \pm 0 . .86$ \\
\hline & 0.5004 & $80.22 \pm 0.45$ & $24.42 \pm 1.02$ & $86.91 \pm 0.54$ & $45.35 \pm 1.90$ \\
\hline & 1.014 & $87.91 \pm 0.44$ & $76.79 \pm 1.26$ & $89.75 \pm 0.44$ & $102.4 \pm 1.80$ \\
\hline & 2.059 & $92.25 \pm 0.61$ & $96.53 \pm 1.01$ & $88.67 \pm 0.43$ & $123.68 \pm 2.12$ \\
\hline \multirow[t]{4}{*}{ Ahmed } & 0.1011 & $26.15 \pm 0.19$ & $2.37 \pm 1.30$ & $52.99 \pm 0.29$ & $6.19 \pm 1.07$ \\
\hline & 0.5010 & $68.27 \pm 0.28$ & $18.02 \pm 0.51$ & $86.91 \pm 0.22$ & $32.44 \pm 1.10$ \\
\hline & 1.002 & $90.46 \pm 0.99$ & $39.30 \pm 1.66$ & $89.61 \pm 0.45$ & $88.04 \pm 1.11$ \\
\hline & 2.051 & $92.25 \pm 0.77$ & $64.81 \pm 1.53$ & $89.0 \pm 0.42$ & $192.03 \pm 2.12$ \\
\hline \multirow{4}{*}{$\begin{array}{l}\text { Twinings } \\
\text { (Green tea leaves } \\
\text { powder) }\end{array}$} & 0.1014 & $16.08 \pm 0.27$ & $1.45 \pm 0.29$ & $29.43 \pm 0.39$ & $4.89 \pm 0.91$ \\
\hline & 0.5004 & $88.05 \pm 0.31$ & $15.85 \pm 1.51$ & $87.9 \pm 0.49$ & $28.14 \pm 1.18$ \\
\hline & 1.011 & $86.91 \pm 0.19$ & $31.5 \pm 1.07$ & $91.03 \pm 0.39$ & $81.25 \pm 1.89$ \\
\hline & 2.014 & $90.98 \pm 0.20$ & $91.7 \pm 2.35$ & $93.06 \pm 0.33$ & $138.36 \pm 2.01$ \\
\hline
\end{tabular}


$(0.6605)>$ Society $(0.649)>$ Tata $(0.6232)>$ Leone $(0.578)>$ Twinings $(0.4951)>$ Ahmed $(0.3916)$. The analytical data clearly showed that their relationship were not linear (Table 6). However, in the present study, it was observed that, free radical scavenging activity of tea infusion determined by DPPH radical scavenging method were not increased with increasing of their polyohenol contents. Moreover, antioxidant activity decreased with increasing brewing period for larger amount of tea leaves powder inspite of their higher concentration of polyphenolic content.

Table 6. Correlation coefficients between free radical scavenging activity and polyphenol content of black tea leaves powder samples

\begin{tabular}{llc}
\hline \hline \multirow{2}{*}{$\begin{array}{l}\text { Tea leaves } \\
\text { powder products }\end{array}$} & \multicolumn{2}{c}{$\begin{array}{c}\text { Correlation coefficients (r)* } \\
\text { brewing period }\end{array}$} \\
\cline { 2 - 3 } & $1(\mathrm{~min})$ & $5(\mathrm{~min})$ \\
\hline Leone & 0.4599 & 0.578 \\
Alkozay & 0.7152 & 0.6697 \\
Ahmed & 0.7755 & 0.3916 \\
Lulu & 0.7883 & 0.7201 \\
Lipton & 0.3365 & 0.4698 \\
Society & 0.6543 & 0.6490 \\
Kanan Devan & 0.4164 & 0.6605 \\
Tata & 0.2705 & 0.6232 \\
Red Label & 0.3049 & 0.8499 \\
Twinning & 0.3601 & 0.4951 \\
\hline \hline
\end{tabular}

*In the linear regression analysis, polyphenolic content was regarded as $\mathrm{X}$ and \% DPPH radical scavenging activity as $\mathrm{Y}$.

\section{Conclusion}

Free radical scavenging activity depends on the amount of tea leaves used and the brewing period. From this study, it is clear that infusion of black or green tea bag for 1 or $2 \mathrm{~min}$ is enough to get higher antioxidant activity. Boiling of black tea powder products for longer time loses its antioxidant properties as well as decrease its health beneficial effect. Therefore, shorter boiling time is better for large amount of powder or small amount of powder should brew for minimum $5 \mathrm{~min}$ for getting higher antioxidant activity. However, several methods need to employ to study the antioxidant activity of tea infusion to find out the reason behind decreased free radical scavenging activity with increasing infusion time inspite of increasing polyphenol content.

\section{Acknowledgement}

The authors are grateful to Sana E. Taher, Shaima A. Jenebi, Asma Y. Rashid, Nehad M. Nafad and Hunain N. Salman, B. Pharm students of Dubai Pharmacy College for their valuable help in the preparation of tea infusion during carrying out this study.

\section{References}

Arab, L., Liu, W., Elashoff, D. 2009. Green and black tea consumption and risk of stroke: a meta-analysis. Stroke, 40: 1786-1792.

Bors, W., Michel, C., Stettmaier, K. 1997. Antioxidant effects of flavonoids. Bio-factors, 6: 399-402.

Bors, W., Heller, W., Michel, C., Saran, M. 1990. Flavonoids as antioxidants: determination of radical scavenging efficiencies. Methods in Enzymology, 186: 343-355.

Buschman, J.L. 1998. Green tea and cancer in humans: a review of the literature. Nutrition and Cancer, 31: 151-159.

Cao, G.H., Sofic, E., Prior, R.L. 1996. Antioxidant capacity of tea and common vegetables. Journal of Agricultural and Food Chemistry, 44: 3426-3431.

Chen, Y., Wang, M., Rosen R.T., Ho, C.T. 1999. 2,2Diphenyl-1-picrylhydrazil radical scavenging active components from Polygonum multiflorum Thunb. Journal of Agricultural and Food Chemistry, 47: 2226-2228.

Gramza, A., Pawlak-Lemañska, K., Korczak, J., Wsowicz, E., Rudzinska, M. 2005. Tea extracts as free radical scavengers. Polish Journal of Environmental Studies, 14: 861-867.

Gupta, J., Siddique, Y.H., Beg, T., Ara, G., Afzal, M. 2008. A review on the beneficial effects of tea polyphenols on human health. International Journal of Pharmacology, 4: 314-338.

Higdon, J.V., Frei, B. 2003. Tea catechins and polyphenols: health effects, metabolism, and antioxidant functions. Critical Review in Food Science and Nutrition, 43: 89-143.

Lambert, J.D., Yang, C.S. 2003. Cancer chemopreventive activity and bioavailability of tea and tea polyphenols. Mutation Research, 523-524: 201-208.

Lin, Y.L., Tsai, S.H., Lin-Shiau, S.Y., Ho, C.T., Lin, J.K. 1999. Theaflavin-3,3-digallate from black tea blocks the nitric oxide synthase by downregulating the activation of NF-B in macrophages. European Journal of Pharmacology, 367: 379388. 
Menet, M.C., Sang, S., Yang, C.S., Ho, C.T., Rosen, R.T. 2004. Analysis of Theaflavins and Thearubigins from black tea extract by MALDI-TOF mass spectrometry. Journal of Agricultural and Food Chemistry, 52: 2455-2461.

Narotzki, B., Reznick, A.Z., Aizenbud, D., Levy, Y. 2012. Green tea: a promising natural product in oral health. Archives of Oral Biology, 57: 429-435.

Nessa, F., Ismail, Z., Mohamed, N., Mas Haris, M.R.H. 2004. Free radical scavenging activity of organic extracts and of pure flavonoids of Blumea balsamifera DC. leaves. Food Chemistry, 88: 243252.

Nkubana, A., He, Q. 2008. A comparative study of antioxidant activity between black tea from Rwandan highlands with green and oolong teas from China. International Journal of Food Safety, Nutrition and Public Health, 1: 159-166.

Peterson, J., Dwyer, J., Jacque, P., Rand, W., Prior, W., Chui, K. 2004. Tea variety and brewing techniques influence flavonoid content of black tea. Journal of Food Composition and Analysis, 17: 397-405.

Peters, U., Poole, C., Arab, L. 2001. Does tea affect cardiovascular disease? A meta-analysis. American Journal of Epidemiology, 154: 495-503.

Rice-Evans, C.A., Miller, N.J., Paganga, G. 1996. Structure antioxidant activity relationship of flavonoids and phenolic acids. Free Radical Biology and Medicine, 20: 933-956.

Sanchez-Moreno, C. 2002. Review: Methods used to evaluate the free radical scavenging activity in foods and biological systems. Food Science and Technology International, 8: 121-137.

Satoh, E., Ishii, T., Shimizu, Y., Sawamura, S.I., Nishimura, M. 2001. Black tea extract, thearubigin fraction, counteract the effects of botulinum neurotoxins in mice. British Journal of Pharmacology, 132: 797-798.

Scalbert, A., Monties, B., Janin, G. 1989. Tannins in wood: comparison of different estimation models. Journal of Agricultural and Food Chemistry, 37: 1324-1329.

Su, X., Duan, J., Jiang, Y., Duan, X., Chen, F. 2007. Polyphenolic profile and antioxidant activities of oolong tea infusion under various steeping conditions. International Journal of Molecular Sciences, 8: 1196-1205.

Vita, J.A. 2003. Tea consumption and cardiovascular disease: Effects on endothelial function. The Journal of Nutrition, 133: 3293S-3297S.

Wang, Y., Yang, Z., Wei, X. 2012. Antioxidant activities potential of tea polysaccharide fractions obtained by ultra filtration. International Journal of Biological Macromolecules, 50: 558-564.

Xiao, J., Huo J, Jiang, H., Yang, F. 2011. Chemical compositions and bioactivities of crude polysaccharides from tea leaves beyond their useful date. International Journal of Biological Macromolecules, 49: 1143-1151.

Yang, C.S., Landau, J.M. 2000. Effects of tea consumption on nutrition and health. The Journal of Nutrition, 130: 2409-2412.

Yamaguchi, T., Takamura, H., Matoba T., Terao, J. 1998. HPLC method for evaluation of the freeradical scavenging activity of foods by using DPPH. Bioscience, Biotechnology and Biochemistry, 62: 1201-1204.

Yokozawa, T., Noh, J.S., Park, C.H. 2012. Green tea polyphenols for the protection against renal damage caused by oxidative stress. Evidence-based Complementary and Alternative Medicine: ecm, 2012: 845917. 10. doi:10.1155/2012/845917. Epub 2012 July.

Zuo, Y., Chen, H., Deng, Y. 2002. Simultaneous determination of catechins, caffeine and gallic acids in green, Oolong, black and pu-erh teas using HPLC with a photodiode array detector. Talanta, 57: $307-$ 316. 